\title{
Identifikasi Kualitas Beras Menggunakan Metode k-Nearest Neighbor dan Support Vector Machine
}

\section{Rice Quality Identification using k-Nearest Neighbor and Support Vector Machine Method}

\author{
Sofia Saidah ${ }^{1 *}$, Muhammad Bayu Adinegara ${ }^{2}$, Rita Magdalena ${ }^{3}$, Nor Kumalasari Caecar Pratiwi ${ }^{4}$ \\ ${ }_{1,2,3,4}$ Fakultas Teknik Elektro, Telkom University \\ Jl. Telekomunikasi no 1, Buah Batu, Bandung \\ sofiasaidahsfi@telkomuniversity.ac.id ${ }^{1 *}$, bayuadi@student.telkomuniversity.ac.id ${ }^{2}$, \\ ritamagdalena@telkomuniversity.ac.id ${ }^{3}$, caecarnkcp@telkomuniversity.ac.id ${ }^{4}$
}

\begin{abstract}
Abstrak - Beras merupakan makanan pokok bagi mayoritas penduduk Indonesia. Beragamnya kualitas beras di pasaran menuntut adanya pengawasan terhadap standar kualitas beras. Pengamatan terhadap kualitas beras secara visual rentan terhadap kesalahan dikarenakan subjektifitas setiap pengamat berbeda-beda. Penelitian ini dilakukan dengan mendeteksi kualitas beras berbasis morfologi citra.. Sistem didesain dengan menggunakan dua metode klasifikasi yang berbeda, yaitu k-Nearest Neighbor (K-NN) dan Support Vector Machine (SVM) untuk kemudian diperoleh sistem dengan metode terbaik. Hasil dari penelitian menunjukkan bahwa sistem mampu melakukan identifikasi kualitas beras dengan akurasi terbaik yang diperoleh yaitu 96,67\% ketika digunakan metode $K-N N$ jenis Euclidean dengan nilai $k=1$, dan 96,67\% pada saat digunakan parameter SVM OAO dan OAA dengan tipe kernel Polynomial serta kernel option 7.
\end{abstract}

Kata Kunci: beras, morfologi citra, k-nearest neighbor, support vector machine

\begin{abstract}
Rice is a main food commodity for mostly people in Indonesia. Due to the variety of rice quality in the market, it lead us to have an information about the rice quality standard. The visually observation for checking the quality of quality was susceptible to mistakes due to the subjectivity of every observer is different. The research proposed a system for detecting the quality of rice based on morphological imagery. The system was designed using two different classification methods, namely K-Nearest Neighbor $(K-N N)$ and Support Vector Machine (SVM) for later acquired system with the best method. The results showed that the system is able to identify the quality of rice. The performance of $K$-NN method obtained accuracy 96.67\%. Furthermore, the accuracy of system that used parameters SVM OAO and OAA With Polynomial kernel type as well as kernel option 7, has the same accuracy which is $96.67 \%$.
\end{abstract}

Keywords: rice, image morphology, $k$-nearest neighbor, support vector machine

\section{Pendahuluan}

Beras masih menjadi bahan konsumsi utama sebagian besar masyarakat Indonesia. Beras adalah bagian bulir dari padi atau gabah yang telah dipisah dari sekam. Pada salah satu tahap

TELKA, Vol.5, No.2, November 2019, pp. 114 121

ISSN (e): 2540-9123

ISSN (p): 2502-1982 
pemrosesan hasil panen padi, gabah ini ditumbuk dengan alat tradisional lesung atau digiling sehingga bagian luarnya atau kulit dari gabah terlepas dari isinya. Dari bagian isi inilah terdapat warna putih, kemerahan, ungu, atau hitam, yang disebut beras. Banyaknya jenis beras yang terdapat di Indonesia, mengakibatkan perlu adanya pengawasan terhadap kualitas beras..

Beberapa penelitian terdahulu terkait dengan deteksi kualitas beras yang sudah pernah dilakukan, diantaranya adalah penelitian yang dilakukan oleh R.Suminar dkk yang melakukan klasifikasi kualitas beras berdasarkan ciri fisik berbasis pengolahan citra digital [1]. Penelitian yang dilakukan oleh P Utomo yang merancang sistem klasifikasi jenis beras menggunakan Metode Learning Vector Quantization [2]. Selain itu, penelitian terkait juga dilakukan oleh Elly Antika dkk, yang melakukan identifikasi terhadap kualitas beras merah berbasis pengolahan citra digital. Penelitian ini menggunakan pengelolahan citra digital untuk mengklasifikasi kualitas mutu beras merah berdasarkan SNI dengan metode thresholding, median filtering, dan connected component caballing [3]. Penelitian yang dilakukan oleh I.S. Wibisono dan S. Mujiyono membantu identifikasi kualitas beras berdasarkan nilai threshold, warna dan ukuran terhadap 20 data uji, data tersebut dibagi menjadi 3 cluster. Cluster 1 merupakan beras kualitas buruk, cluster 2 beras kualitas sedang, dan cluster 3 beras kualitas baik [4]. Aldion Cahya Imanda juga melakukan penelitian terkait klasifikasi varietas padi unggulan dengan metode modified k-NN [5].

Pada penelitian ini, sistem dirancang untuk melakukan proses identifikasi terhadap kualitas beras berbasis morfologi citra dengan membandingkan dua metode klasifikasi, yakni k-NN dan SVM untuk kemudian diperoleh sistem dengan metode dan parameter terbaik.

\section{Metode Penelitian}

Beras yang diuji pada penelitian ini adalah beras yang di produksi di Indonesia, yaitu beras pandan wangi dan dan beras IR 64/ Setra Ramos. Beras Pandan Wangi memiliki ciri-ciri: bentuk membulat, agak panjang, mempunyai bagian berkapur pada bagian perutnya yang ditunjukkan dengan warna putih (white belly). Butiran gabah dan beras pandanwangi menunjukkan bahwa Beras Pandanwangi termasuk dalam kategori beras berukuran panjang (rata-rata $6.2 \mathrm{~mm}$ ) dan berbentuk agak bulat (rata-rata nisbah $\mathrm{p} / 1=2.4$ ) [6]. Sedangkan beras IR 64/ setra ramos ini memiliki ciri fisik agak panjang / lonjong, tidak bulat.

Citra beras diperoleh dengan cara mengambil gambar beras dengan dual kamera smartphone Android yang memiliki resolusi 17 MP dan 20MP. Citra beras diambil dengan warna latar yang berbeda-beda, diantaranya adalah warna hitam, merah dan hijau.

\section{1 k-Nearest Neighbor (k-NN)}

Tujuan dari algoritma ini adalah mengklasifikasikan obyek baru berdasarkan atribut dan training sample. K-NN memiliki beberapa kelebihan yaitu ketangguhan terhadap training data yang memiliki banyak noise dan efektif apabila jumlah training data-nya besar. Sedangkan, kelemahan K-NN adalah perlu menentukan nilai dari parameter $k$ (jumlah dari tetangga terdekat), training berdasarkan jarak tidak jelas mengenai jenis jarak apa yang harus digunakan dan atribut mana yang harus digunakan untuk mendapatkan hasil terbaik, dan biaya komputasi cukup tinggi karena diperlukan perhitungan jarak dari tiap query instance pada keseluruhan training sample [7].

Salah satu jenis k-NN yang banyak digunakan adalah Euclidean Distance. Perhitungan jarak antara data uji dan data latih dengan metode Euclidean Distance adalah sebagai berikut

$$
D_{(a, b)}=\sqrt{\sum_{k=1}^{d}\left(a_{k}-b_{k}\right)^{2}} .
$$

Metode lainnya untuk menghitung dekat atau jauhnya tetangga antara dua titik yaitu $a$ dan $b$ juga terdapat Cosine, Cityblock atau Manhattan, dan Correlation dengan rumus sebagai berikut:

$$
\text { Cityblock }=\sum_{k=1}^{N}|a(k)-b(k)|,
$$




$$
\begin{gathered}
\text { Cosine }=\frac{\Sigma_{k}\left(a_{k} \times b_{k}\right)}{\sqrt{\Sigma_{k} a_{k}^{2}} \sqrt{\Sigma_{k} b_{k}^{2}}}, \\
\text { Correlation }=\frac{1}{2}\left(1-\frac{\sum_{k=1}^{N}\left(a_{k}-\bar{a}\right)\left(b_{k}-\bar{b}\right)}{\sqrt{\sum_{k=1}^{N}\left(a_{k}-\bar{a}\right)^{2}} \sqrt{\sum_{k=1}^{N}\left(b_{k}-\bar{b}\right)^{2}}}\right),
\end{gathered}
$$

dimana mat matriks $D_{(a, b)}$ adalah jarak skalar dari kedua vektor $a$ dan $b$ dari matriks dengan ukuran $d$ dimensi. Vektor $a_{k}$ sebagai data uji, vektor $b_{k}$ sebagai data latih dan $d$ sebagai dimensi data.

\subsection{Support Vector Machine (SVM)}

SVM memiliki sifat yang tidak dimiliki oleh mesin pembelajaran pada umumnya yaitu dalam proses menemukan garis pemisah (hyper-plane) terbaik sehingga diperoleh ukuran margin yang maksimal [8]. Ada dua pilihan untuk mengimplementasikan multiclass SVM, yaitu dengan menggabungkan beberapa SVM biner atau menggabungkan semua data yang terdiri dari bebarapa kelas ke dalam sebuah bentuk permasalahan optimal. Metode yang umum digunakan untuk implementasi multiclass SVM adalah One-Againts-All (OAA) dan One-Against-One (OAO). Metode OAA dilakukan dengan cara membangun $\mathrm{k}$ buah buah model SVM biner (k adalah jumlah kelas). Metode OAO dilakukan dengan membangun $\mathrm{k}(\mathrm{k}-1) / 2$ buah model klasifikasi biner ( $\mathrm{k}$ adalah jumlah kelas) [8]. Menurut [9] SVM memiliki kemampuan yang handal dalam hal generalisasi. SVM dapat menemukan solusi optimal, selalu mencapai solusi yang sama untuk setiap kali dilakukannya percobaan. Margin adalah jarak antara hyper-plane tersebut dengan pattern yang terdekat dari masing-masing kelas. Pattern yang paling dekat inilah yang disebut dengan support vector.

\subsection{Desain Umum Sistem}

Secara umum, perancangan sistem teridri dari proses akuisis citra, preprocessing, ektraksi ciri dan berakhir di proses klasifikasi. Perancangan sistem dijelaskan dengan skema pada Gambar 1.

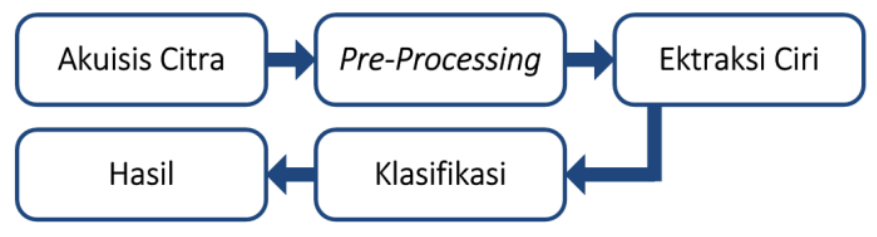

Gambar. 1 Diagram Blok Model Sistem

Akuisisi citra merupakan pemetaan suatu scene menjadi citra kontinyu dengan penggunaan suatu sensor sehingga diperoleh citra digital. Menurut [10] akuisisi citra dilakukan menggunakan smartphone dual kamera 17 MP dan 20 MP sehingga didapatkan file citra dalam bentuk digital. Citra diambil dalam ruangan dengan cukup intensitas cahaya dan dalam keadaan situasi dan kondisi yang berubah intensitas pencahayaannya. Posisi saat men-scan citra tersebut harus dalam posisi portrait. Pada sistem ini dibutuhkan citra untuk proses latih danuji yakni sebanyak 3 sampel beras pandan wangi.

Pre-processing merupakan tahap yang bertujuan untuk meningkatkan kualitas citra yang diperoleh agar lebih mudah diproses pada tahap selanjutnya. Proses dari pre-processing adalah resize dan pengubahan citra RGB menjadi citra grayscale. Tujuan pre-processing untuk mempermudaj proses komputerisasi untuk mengenali sebuah objek atau benda [10]. Tahap ini dilakukan baik pada citra latih maupun citra uji. Blok diagram dapat dilihat pada Gambar 2. Proses yang terdapat dalam pre-processing adalah; citra masukan, cropping citra, RGB to grayscale, deteksi tepi, filling, dan resize citra. 
Untuk mendapatkan informasi penting pada sebuah citra maka dilakukan ekstrasi ciri Principal Component Analysis dan Gray Level Co-occuraence Matrix (GLCM). Pada proses klasifikasi akan dilakukan pengambilan ciri terhadap citra, dimana dua proses yang akan dilakukan dengan memisahkan citra menjadi citra latih dan citra uji. Pada penelitian ini metode klasifikasi yang diterapkan adalah K-Nearest Neighbor (K-NN) dan Support Vector Machine (SVM). Parameter SVM yang digunakan adalah jenis kernel polynomial dan gausian dan jenis multiclass One against One (OAO) dan One against All (OAA).

Proses klasifikasi ini menindaklanjuti hasil dari proses ekstraksi ciri. Semua informasi yang sudah tercatat akan diklasifikasikan dengan menggunakan k- Nearest Neighbour dengan nilai $\mathrm{k}=1,3,5$, dan 7 , serta menggunakan jarak euclidean, cityblock dan cosine. Pada dasarnya algoritma ini akan menghitung jarak antara nilai ciri yang dimiliki oleh data uji menuju data latih. Lalu, jarak-jarak tersebut akan dipilih jarak terpendeknya. Setelah itu, klasifikasi mengeluarkan hasil apakah citra uji termasuk kualitas beras yang bagus atau tidak, atau tidak terdeteksi.

Pada metode klasifikasi SVM, output GLCM dengan lima nilai ciri tekstural yaitu energy, contrast, homogenity, entropy dan correlation menjadi input awal. Data input yang digunakan merupakan data non-linear maka diperlukan kernel. Kernel berfungsi untuk memetakan data pada ruang dimensi awal ke ruang dimensi yang baru. Ruang dimensi baru pada umumnya relatif lebih tinggi. Setelah menentukan jenis kernel, selanjutnya adalah menentukan metode multiclass pada SVM. Menentukan multiclass dilakukan dengan cara pelatihan data yang diambil dari database dimana data citra latih disimpan untuk selanjutnya diproses. Setelah proses pelatihan selesai maka proses terakhir adalah pengujian. Proses pengujian ini akan membandingkan data citra uji dengan data citra latih yang sebelumnya telah diproses [10].

Gambar 2 menggambarkan blok diagram sistem keseluruhan, baik untuk proses pengujian data latih maupun data uji. Performansi sistem dapat diukur berdasarkan parameter akurasi. Akurasi merupakan cara untuk mengukur performansi dari suatu sistem dalam mengenali masukan yang diberikan, sehingga menghasilkan keluaran yang sesuai. Secara matematis persamaan perhitungan akurasi dapat dituliskan menjadi:

$$
\begin{aligned}
& \text { Akurasi }=\frac{T P+T N}{T P+T N+F P+F N} \times 100 \% \\
& \text { Presisi }=\frac{T P}{F P+T P} \times 100 \% \\
& \text { Recall }=\frac{T P}{F N+T P} \times 100 \%
\end{aligned}
$$

Dimana TP adalah True Positive, yaitu jumlah data positif yang terklasifikasi dengan benar oleh sistem. TN adalah True Negative, yaitu jumlah data negatif yang terklasifikasi dengan benar oleh sistem. FN adalah False Negative, yaitu jumlah data negatif namun terklasifikasi salah oleh sistem. Dan FP adalah False Positive, yaitu jumlah data positif namun terklasifikasi salah oleh system. Berdasarkan nilai True Negative (TN), False Positive (FP), False Negative (FN), dan True Positive (TP) dapat diperoleh nilai akurasi, presisi dan recall. Nilai akurasi menggambarkan seberapa akurat sistem dapat mengklasifikasikan data secara benar. Dengan kata lain, nilai akurasi merupakan perbandingan antara data yang terklasifikasi benar dengan keseluruhan data. Gambar 2 menunjukan blok diagram sistem secara umum.

\section{Hasil dan Pembahasan}

Pengujian dilakukan untuk mengetahui parameter-parameter apa saja yang terbaik untuk mengidentifikasi kualitas beras menggunakan metode K-NN dan SVM. Pada tahap pengujian ini, beberapa variabel pada 90 data uji akan diubah dengan tujuan untuk mendapatkan performansi dan akurasi sistem yang terbaik. Untuk itu telah dilakukan pembuatan pengujian melalui aplikasi Matlab R2017a dengan format yang sama yakni ekstraksi ciri menggunakan PCA dan GLCM serta klasifikasi menggunakan K-Nearest Neighbor (K-NN) dan Support Vector Machine (SVM). 


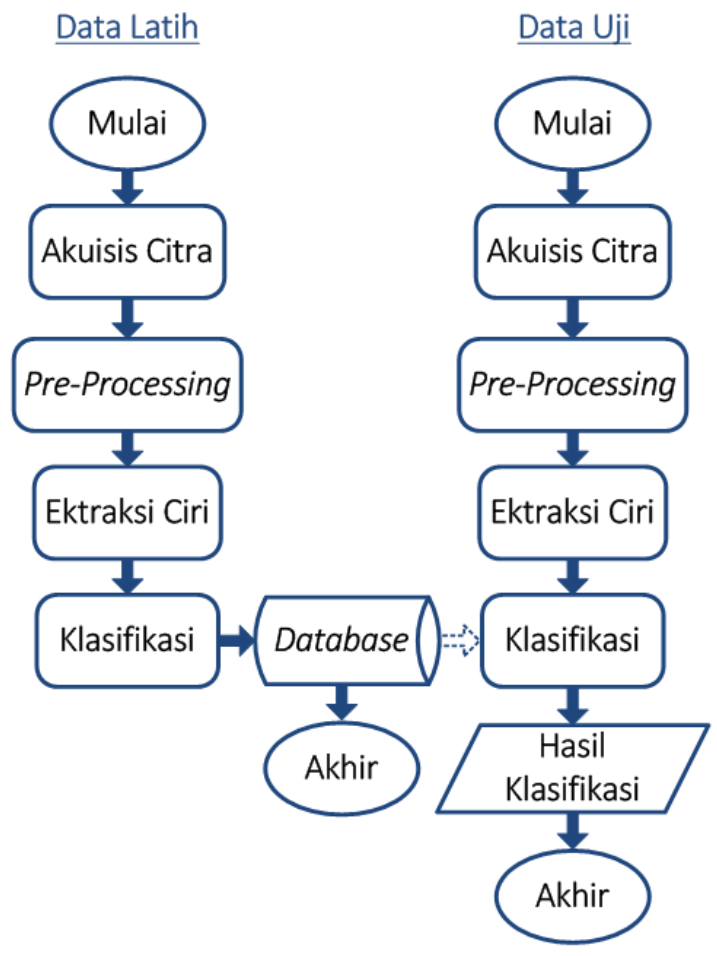

Gambar 2. Blok diagram sistem keseluruhan.

\subsection{Pengaruh Warna Latar terhadap Akurasi Sistem}

Pada skenario pertama dilakukan pengujian terhadap nilai rata-rata akurasi system pada 90 data uji dengan latar merah, hitam dan putih masing-masing 30 data untuk mengetahui pengaruh warna latar terhadap performansi sistem. Hasil pengujian warna latar yang digunakan ditunjukkan pada Tabel 1.

Tabel 1. Pengaruh warna latar terhadap akurasi sistem.

\begin{tabular}{cccc}
\hline \multirow{2}{*}{ Warna Latar } & \multicolumn{3}{c}{ Akurasi Sistem } \\
\cline { 2 - 4 } & k-NN & SVM (OAO) & SVM (OAA) \\
\hline Merah & $55,42 \%$ & $73,33 \%$ & $73,33 \%$ \\
Hitam & $85,00 \%$ & $90,00 \%$ & $90,00 \%$ \\
Putih & $79,17 \%$ & $80,00 \%$ & $73,33 \%$ \\
\hline
\end{tabular}

Hasil pengujian pada Tabel 1 menunjukkan tingkat akurasi sistem pada latar hitam memiliki nilai akurasi yang paling tinggi yakni sebesar $85,00 \%$ ketika menggunakan metode $\mathrm{k}-\mathrm{NN}$, dan akurasi 90,00\% ketika menggunakan metode klasifikasi SVM (OAO) maupun SVM (OAA). Tingginya keakuratan warna latar hitam baik dengan metode K-NN maupun SVM, dikarenakan warna latar hitam sangat kontras dengan objek butir beras yang berwarna putih sehingga objek lebih terlihat jelas dan proses identifikasi akan lebih akurat.

\subsection{Pengaruh Ukuran Citra terhadap Akurasi Sistem}

Pada skenario kedua dilakukan pengujian ukuran citra pada 30 data uji berwarna latar hitam untuk kemudian dilakukan analisis terhadap performansi system dengan cara melakukan proses resizing dari data dengan format JPG yang asli ke dalam ukuran 128x128, 256x256 dan 512x512. Hasil pengujian untuk pengaruh ukuran citra terhadap akurasi dapat dilihat pada Tabel 2. 
Tabel 2. Pengaruh Ukuran Citra terhadap Akurasi Sistem

\begin{tabular}{cccc}
\hline \multirow{2}{*}{ Ukuran Citra } & \multicolumn{3}{c}{ Akurasi Sistem } \\
\cline { 2 - 4 } & k-NN & SVM (OAO) & SVM (OAA) \\
\hline $128 \times 128$ & $75,56 \%$ & $73,33 \%$ & $63,33 \%$ \\
$256 \times 256$ & $73,33 \%$ & $40 \%$ & $50 \%$ \\
$512 \times 512$ & $73,33 \%$ & $90 \%$ & $90 \%$ \\
\hline
\end{tabular}

Dari Tabel 2, terlihat pengaruh proses resizing terhadap akurasi sistem. Pada klasifikasi KNN, ukuran citra paling kecil yaitu $128 \times 128$ memberikan akurasi paling tinggi yaitu sebesar 75,56\%. Sedangkan pada ukuran citra 256x256 dan 512x512 menunjukkan hasil akurasi yang sama yaitu sebesar 73,33 \%. Berbeda dengan K-NN, pada metode klasifikasi SVM, ukuran citra paling kecil yaitu $128 \times 128$ tidak menunjukkan akurasi paling tinggi. Sedangkan pada ukuran citra 256x256 dan 512x512 berturut turut menunjukkan hasil akurasi yang paling rendah dan paling tinggi dengan range yang lebih tinggi daripada metode K-NN. Dalam hal ini, semakin kecil ukuran resize maka akurasi semakin baik, ini dikarenakan ketika citra dengan resolusi yang besar diubah menjadi lebih kecil maka terjadi penumpukan pixel yang lebih padat dan pixel saling berdekatan. Fenomena ini mengakibatkan citra menjadi lebih detail. Lain halnya apabila resize dilakukan dengan mengubah citra dengan resolusi kecil menjadi besar seperti mengubah dari ukuran 128x128 menjadi 1024x1024 maka citra akan terlihat buram dan tidak jelas, serta terdapat banyak distorsi, ini dikarenakan pixel yang renggang dan tidak padat.

\subsection{Pengaruh Jenis k-NN terhadap Akurasi Sistem}

Pada skenario ketiga ini dilakukan pengujian jenis jarak K-NN terhadap akurasi sistem. Jumlah data uji yang digunakan yaitu 30 data uji dengan warna latar hitam dan ukuran citra yang digunakan adalah $128 \times 128$. Jenis k-NN yang digunakan adalah euclidean, cosine, cityblock dan correlation. Hasil pengujian pengaruh jenis k-NN terhadap akurasi tertuang dalam Tabel 3.

Tabel 3. Pengaruh jenis k-NN terhadap akurasi sistem.

\begin{tabular}{cc}
\hline Jenis k-NN & Akurasi Sistem \\
\hline Euclidean & $96.67 \%$ \\
Cosine & $86.67 \%$ \\
Cityblock & $69.67 \%$ \\
Correlation & $83.33 \%$ \\
\hline
\end{tabular}

Pada skenario ini jenis K-NN berpengaruh terhadap akurasi sistem sesuai dengan hasil yang ditunjukkan oleh Tabel 3. Pada jenis K-NN cityblock didapat hasil akurasi yang paling kecil yakni sebesar $69,17 \%$ sedangkan hasil akurasi terbesar saat jenis K-NN menggunakan euclidean yaitu sebesar 96,67\%. Lalu pada jenis cosine diperoleh hasil 86,67\%. Dari tabel tersebut dapat disimpulkan bahwa jenis K-NN yang terbaik adalah euclidean dengan akurasi 96, 67\%. Hal ini dikarenakan peta jarak euclidean dapat dihasilkan oleh algoritma sekuensial yang efektif. Euclidean ini berbasis pada teorema pitagoras untuk mendapatkan jarak secara garis lurus dari titik $a$ ke titik $b$, sedangkan pada cityblock untuk mendapatkan jarak dari titik $a$ ke $b$ tersebut, nilai jarak harus bergerak sepanjang satu dimensi ruang pada suatu waktu. Secara analogi, jenis KNN ini tidak dapat memotong secara diagonal tetapi harus berjalan melewati kedua dimensi blok. Sementara pada cosine, harus melihat sudut antara dua vektor, dimana jarak $a$ dan $b$ dihitung dari cosinus kedua vektor titik $a$ dan $b$. Hal ini mengakibatkan jarak $a$ dan $b$ bisa saja menghasilkan nilai jarak yang lebih jauh dibanding menggunakan euclidean distance yang secara analogi menghitung jarak titik $a$ dan $b$ dengan menarik garis lurus saja. 


\subsection{Pengaruh Nilai k pada k-NN terhadap Akurasi Sistem}

Pada skenario keempat, variabel pengujian adalah nilai $\mathrm{k}$ dari proses $\mathrm{K}-\mathrm{NN}$, dengan nilai $\mathrm{k}$ yang akan digunakan adalah 1,3,5,7, dan 9. Data uji yang digunakan adalah 30 data uji dengan warna latar hitam, ukuran citra 128x128 dan jenis k-NN Euclidean. Hasil pengujian pengaruh nilai k-NN terhadap akurasi system ditunjukkan pada Tabel 4.

Tabel 4. Pengaruh nilai k pada k-NN terhadap akurasi sistem.

\begin{tabular}{cc}
\hline Nilai $\mathrm{k}$ & Akurasi Sistem \\
\hline 1 & $96.67 \%$ \\
3 & $83.33 \%$ \\
5 & $92.50 \%$ \\
7 & $93.33 \%$ \\
9 & $90.83 \%$ \\
\hline
\end{tabular}

Dari Tabel 4 terlihat bahwa akurasi terbaik didapatkan ketika metode k-NN menggunakan nilai $\mathrm{k}=1$. Hal ini dikarenakan apabila nilai $\mathrm{k}$ ditetapkan $\mathrm{k}=1$ maka objek hanya ditetapkan ke kelas tetangga tunggal terdekat dan ini menyebabkan error rate yang kecil, karena $\mathrm{k}=1$ hanya akan membandingkan satu titik yang paling dekat. Lain hal nya apabila ditetapkan $\mathrm{k}=3$, maka objek akan dibandingkan dengan tiga tetangga berdekatan dan ini akan menyebabkan akurasi akan mengalami penurunan mengingat adanya objek yang similar.

\subsection{Pengaruh Kernel Option dan Tipe Kernel pada SVM terhadap Akurasi Sistem}

Skenario kelima adalah perbandingan klasifikasi SVM dengan parameter pengujian tipe kernel dan kernel option. Pengujian dilakukan dengan menggunakan 30 data uji dengan warna latar hitam dan ukuran citra 512x512. Sementara parameter lainnya yaitu ciri statistik menggunakan kombinasi energy, correlation, dan entropy , dengan besar sudut gabungan $(0,45$, 90, 135), jarak 1, level kuantisasi 32. Hasil pengujian tipe kernel dan kernel option pada SVM terhadap akurasi tertuang pada Tabel 5 dan Tabel 6.

Tabel 5. Pengaruh tipe kernel option pada SVM terhadap akurasi sistem.

\begin{tabular}{ccc}
\hline \multirow{2}{*}{ Tipe Kernel } & \multicolumn{2}{c}{ Akurasi } \\
\cline { 2 - 3 } & SVM OAO & SVM OAA \\
\hline Polynomial & $96.66 \%$ & $96.66 \%$ \\
Gausian & $70.00 \%$ & $63.33 \%$ \\
\hline
\end{tabular}

Tabel 6. Pengaruh kernel option pada SVM terhadap akurasi sistem.

\begin{tabular}{ccc}
\hline \multirow{2}{*}{$\begin{array}{c}\text { Oprnel } \\
\text { Option }\end{array}$} & \multicolumn{2}{c}{ Akurasi } \\
\cline { 2 - 3 } & SVM (OAO) & SVM (OAA) \\
\hline 1 & $76.66 \%$ & $63.33 \%$ \\
5 & $86.66 \%$ & $76.66 \%$ \\
7 & $93.33 \%$ & $93.33 \%$ \\
9 & $96.66 \%$ & $96.66 \%$ \\
11 & $80.00 \%$ & $90.00 \%$ \\
\hline
\end{tabular}

Dari hasil pengujian tipe kernel pada Tabel 5 dapat disimpulkan bahwa akurasi tertinggi diperoleh ketika digunakan kernel polynomial. Hal ini dikarenakan objek yang digunakan sebagai data uji berupa objek acak, sehingga kernel polynomial cocok digunakan pada sistem ini. 
Sedangkan, hasil pada Tabel 6 menunjukan bahwa kernel option 7 mendapatkan hasil yang paling optimal pada saat digunakan SVM OAO maupun OAA.

\section{Kesimpulan}

Dari hasil analisis dan pengujian simulasi yang sudah dilakukan, dihasilkan beberapa kesimpulan sebagai berikut: intensitas cahaya yang paling baik digunakan adalah dalam kondisi terang. Warna latar yang paling baik digunakan untuk mengetahui kualitas grade beras yaitu ialah warna latar hitam. Faktor resize mempengaruhi akurasi dan ukuran citra yang terbaik. Pada penelitian ini jenis K-NN yang paling baik digunakan adalah euclidian distance dengan nilai $\mathrm{K}=1$, memperoleh akurasi sebesar 96,67 \%. Parameter pengujian SVM adalah kernel option dan kernel type, berturut-turut memperoleh akurasi sistem optimal saat kernel option 7 dan type kernel polynomial dengan akurasi 96,6\% untuk OAA dan OAO.

\section{Ucapan Terima Kasih}

Terimakasih penulis sampaikan kepada Tim Pakar Pertanian dari IPB yang telah membantu proses validasi data kualitas beras sehingga penelitian ini berjalan dengan lancar.

\section{Referensi}

[1] R. Suminar, B. Hidayat, and R. D. Atmaja, "Klasifikasi Kualitas Beras Berdasarkan Ciri Fisik Berbasis Pengolahan Citra Digital," e-Proceeding Telkom Univ., pp. 0-6, 2012.

[2] P. Utomo, "Sistem Klasifikasi Jenis Beras Menggunakan Metode Learning Vector Quantization," J. Ilm. Ilmu-ilmu Tek., vol. 1, no. 2, pp. 61-67, 2016.

[3] E. Antika, H. Rakhmad, and F. N. Ishaq, "Penentuan Kualitas Mutu Beras Merah Berdasarkan Standart Nasional Indonesia Berbasis Pengolahan Citra Digital," J. Inform. Polinema, vol. 4, no. 2, pp. 125-130, 2018.

[4] I. S. Wibisono and S. Mujiyono, "Segmentasi Fuzzy C-Means Untuk Membantu Identifikasi Kualitas Beras Berdasarkan Nilai Threshold, Warna dan Ukuran," $J$. Multimatrix, vol. I, no. 1, pp. 22-25, 2018.

[5] A. C. Imanda, N. Hidayat, and M. T. Furqon, "Klasifikasi Kelompok Varietas Unggul Padi Menggunakan Modified K- Nearest Neighbor," J. Pengemb. Teknol. Inf. dan Ilmu Komput., vol. 2, no. 8, pp. 2392-2399, 2018.

[6] Nurjaya and N. Maulida, "Tingkat Kesukaan Konsumen pada Atribut Beras Pandanwangi Murni Cinajur," J. Agroscience, vol. 8, no. 1, pp. 1-8, 2018.

[7] R. D. Jayanti, B. Hidayat, and Suhardjo, "Identifikasi Biometrik Rugae Palatina pada Individu Berdasarkan Bentuk dengan Metode Matershed dan KNN," e-proceeding Eng. Telkom Univ., pp. 1-8, 2017.

[8] K. Sembiring, "Penerapan Teknik Support Vector Machine untuk Pendeteksian Intrusi pada Jaringan," Institut Teknologi Bandung, 2007.

[9] E. D. Ginting, "Deteksi Tepi Menggunakan metode Canny dengan Matlab untuk Membedakan Uang Asli dan Uang Palsu," Universitas Gunadarma, 2014.

[10] A. R. Prakoso and R. Magdalena, "Morfologi Citra untuk Analisa Kualitas Beras Menggunakan Metode Klasifikasi Support Vector Machine," e-Proceeding Eng. J., vol. 5, no. 3, pp. 5157-5164, 2018. 